\title{
\# USGS
}

ב

\section{Northwest Area Science}

\section{Northwest Area Facts}

- Population about 12 million

- 43 federally recognized Tribes

- Hydropower provides about two-thirds of electricity supply

- 78 federally listed threatened and endangered species

- 12 active or potentially active volcanoes

- Columbia River system drains more than 260,000 square miles, an area about the size of Texas

- More than 175 square miles covered by glaciers

- More than 900 miles of Pacific Ocean coastline

- More than 2,300 miles of greater Puget Sound coastline

- Some forests store more carbon per unit area than any other area in the world, including the tropics

- 51 percent federal lands

- Significant lead, zinc, silver, and phosphate deposits

\section{USGS Research Units in the Northwest}

Cascades Volcano Observatory

http://vulcan.wr.usgs.gov/

Earthquake Hazards Program

http://earthquake.usgs.gov/regional/pacnw/

Forest and Rangeland Ecosystem Science Center http://fresc.usgs.gov/

Idaho Cooperative Fish and Wildlife Research Unit http://www.coopunits.org//daho

Idaho Water Science Center

http://id.water.usgs.gov/

Oregon Cooperative Fish and Wildlife Research Unit http://www.coopunits.org/Oregon

Oregon Water Science Center http://or.water.usgs.gov/

Washington Cooperative Fish and

Wildlife Research Unit

http://www.coopunits.org/Washington

Washington Water Science Center

http://wa.water.usgs.gov/

Western Coastal and Marine Geology http://walrus.wr.usgs.gov/

Western Fisheries Research Center http://wfrc.usgs.gov/

Western Geographic Science Center http://geography.wr.usgs.gov/

Western Mineral and Environmental Resources Science Center

http://minerals.usgs.gov/west/spokane.htm

\section{Anticipating Climate Change in the Northwest}

The Northwest harbors a rich diversity of natural systems, including marine and freshwater habitats, forests, sage-steppe, high-altitude deserts, wetlands, and grasslands. Climate change, a great environmental and conservation challenge for the 21st century, could alter temperature and precipitation, which would negatively affect natural and developed areas. In 2010, the Northwest Climate Science Center (NWCSC) was established by the U.S. Department of the Interior (DOI) to address the challenges presented by climate change and variability, and brings together the expertise of federal and university scientists.

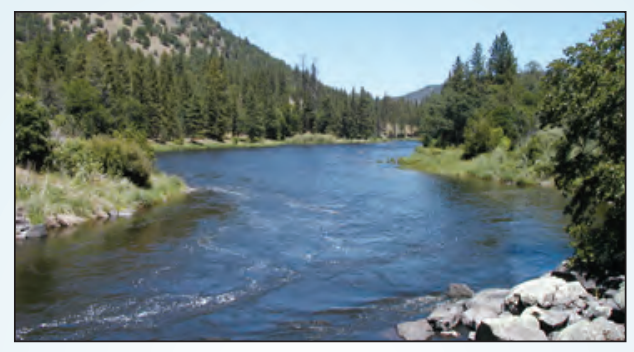

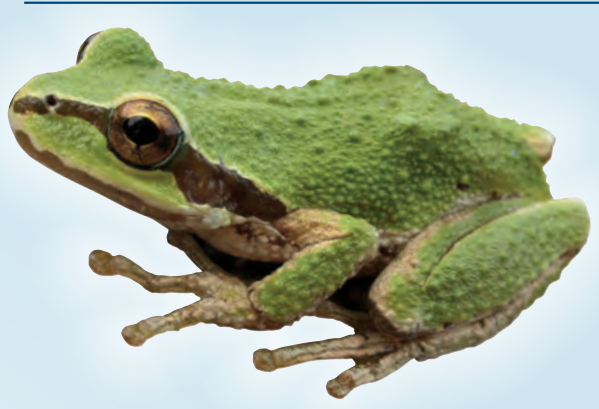

\section{Understanding Ecosystems: from Salmon Recovery to Sage-Steppe Restoration}

USGS conducts research in the Northwest on aquatic and terrestrial species, habitats, and biophysical processes to advance the understanding of complex ecosystem interactions that include anthropogenic impacts. Our scientists develop tools for optimizing ecosystem services and management. Research is conducted throughout the Northwest, with particular focus on the Great Basin, Northwest forests, and the Columbia River, Puget Sound, Elwha River, and Klamath River basins.
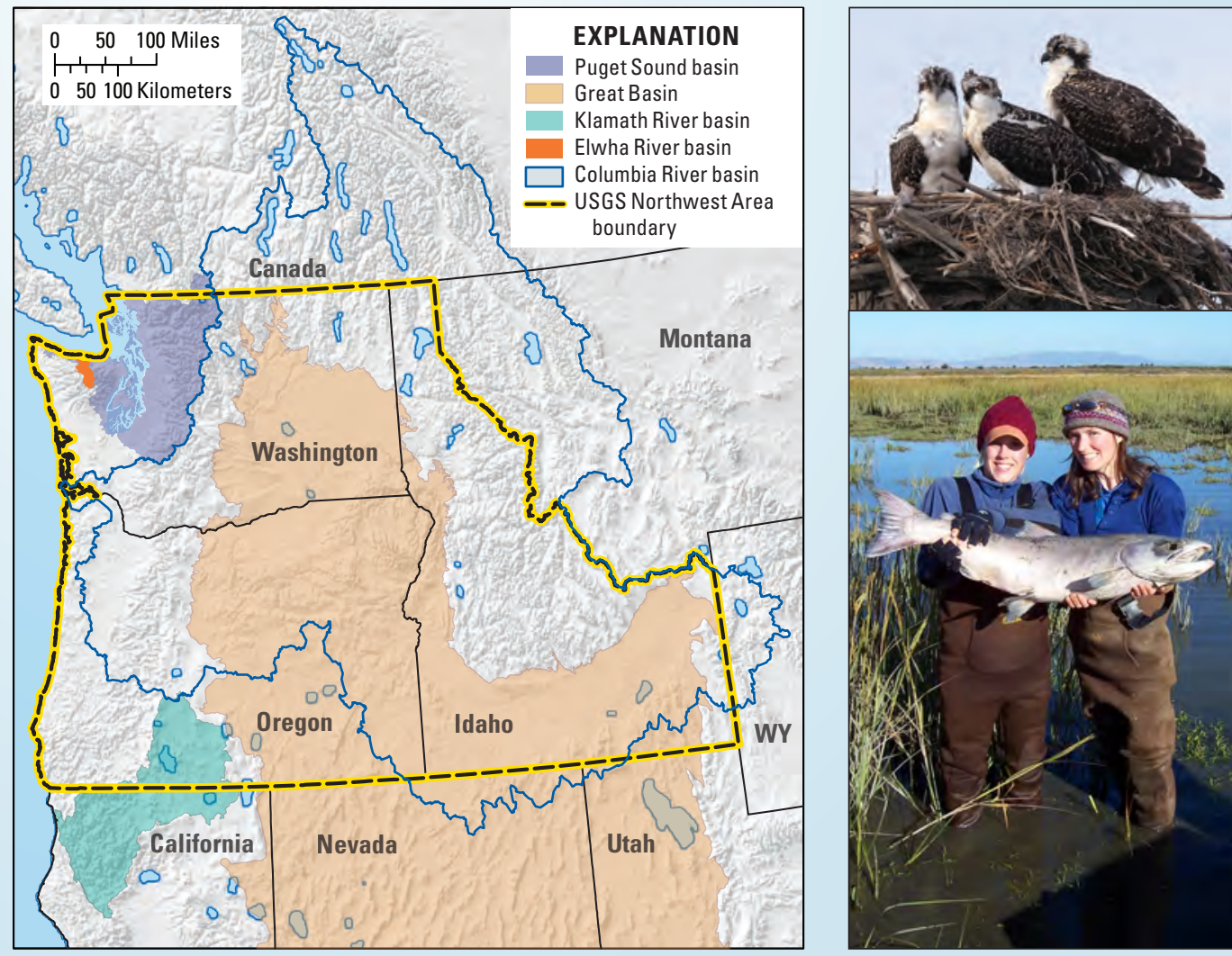


\section{Water Availability and Quality}

USGS scientists measure and assess

streamflow and groundwater quantity and quality throughout the Northwest to determine the status and trends of water resources. USGS also develops tools for allocating water among competing uses in the region, such as aquatic

habitat, hydroelectric power generation, irrigated agriculture, recreation, and public water supply.

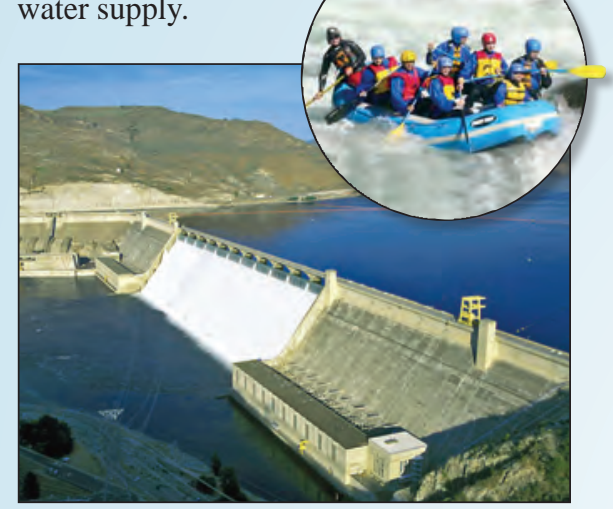

\section{Study Examples}

\section{Coastal Habitats in Puget Sound (CHIPS)}

(http://puget.usgs.gov/): evaluates impacts of urbanization on Puget Sound coastal ecosystems, restoration of large river deltas, and effects of Elwha River dam removals.

\section{Yakima River Basin Water Availability}

(http://wa.water.usgs.gov/projects/ yakimagw/): quantifies water resources in a basin with many competing water demands.

\section{Columbia River Contaminants and Habitat Characterization}

(http://or.water.usgs.gov/proj/Conhab/): tracks the occurrence and food-web effects of polybrominated flame retardants and endocrine disrupting compounds.

\section{Climate-Change Impacts on Temperate Forests}

(http://fresc.usgs.gov/research/StudyDetail. asp?Study ID=433): evaluates impacts on carbon sequestration and biogeochemical cycling in Douglas-

fir forests of Olympic National Park in response to likely changes in precipitation.

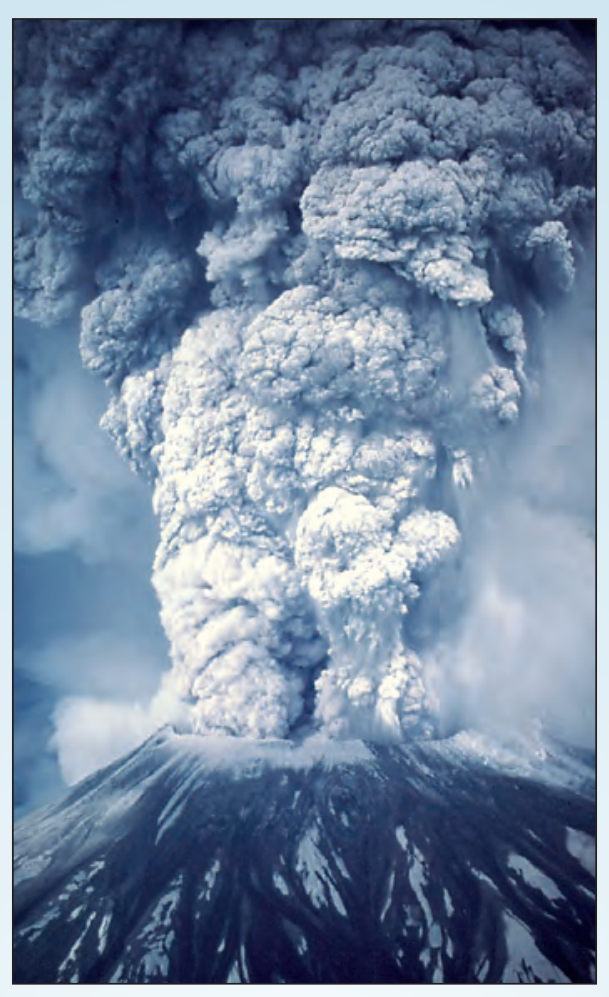

\section{Natural Hazards: Keeping You} Safe and Informed

USGS evaluates natural hazards before they occur to help Northwest communities prepare. Hazards include floods, earthquakes, landslides, tsunamis, volcanic eruptions, and wildfires. USGS also monitors flood stage, and seismic, volcanic, and other potentially hazardous natural activity 24/7 to assist emergency responders with protecting the health, safety, and property of Northwest residents.

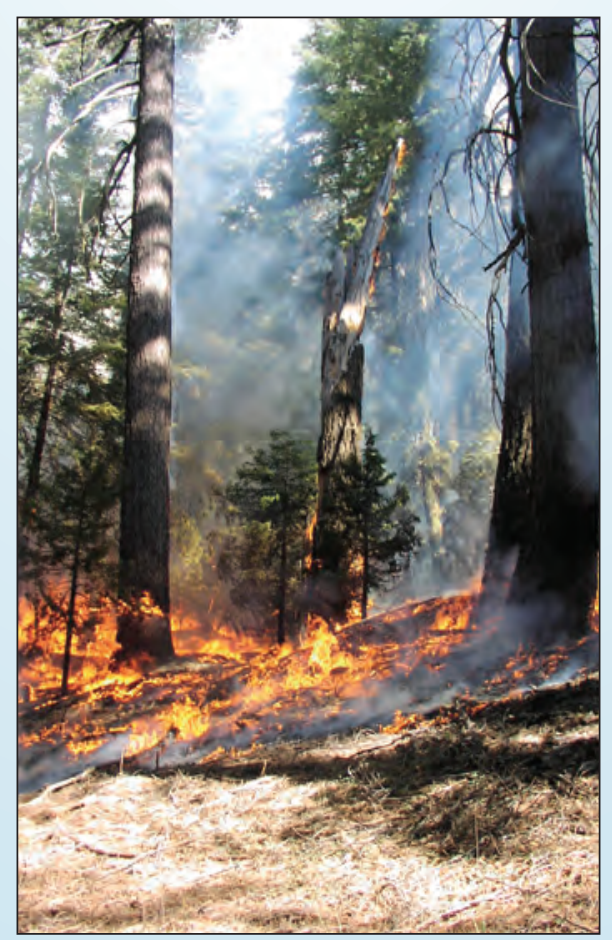

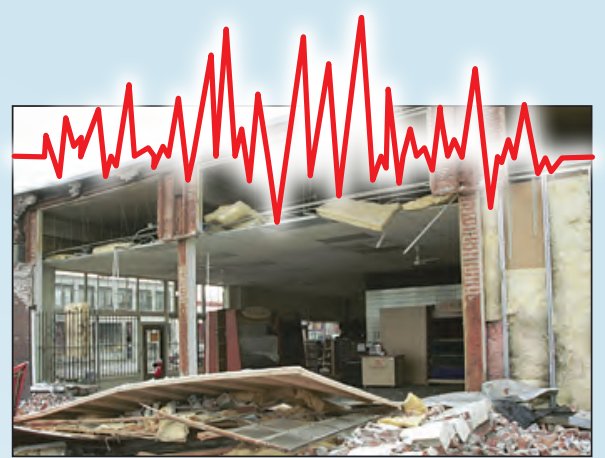

\section{USGS Start with Science}

The USGS Science Strategy

(http://www.usgs.gov/science strategy) focuses USGS research in these areas:

- Core Science Systems

- Climate and Land Use Change

- Energy and Minerals

- Environmental Health

- Ecosystems

- Natural Hazards

- Water

\section{USGS Partners}

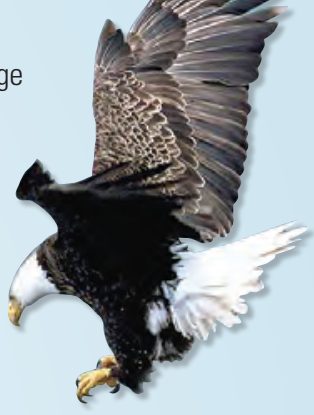

The USGS collaborates with many partners throughout the Northwest, including other federal agencies, tribal, state, and local governments, non-governmental organizations, public utilities, conservation districts, universities, and others.

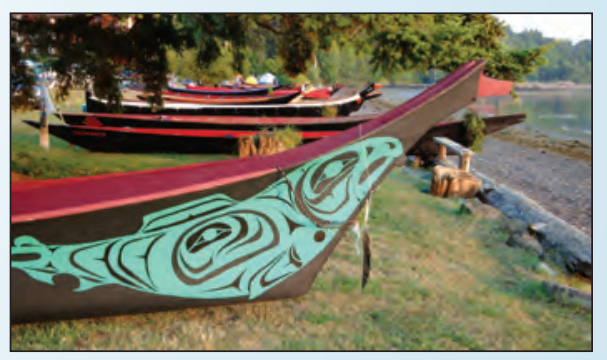

\section{USGS Northwest Area Office}

The USGS Northwest Area Office coordinates USGS science in Idaho, Oregon, and Washington.

\section{For additional information, contact: Leslie A. Dierauf, VMD \\ Regional Executive, USGS Northwest Area 909 First Ave, suite 800 Seattle, WA 98104}

Email: nwa_dropbox@usgs.gov Phone: 206-220-4600 http://www.wr.usgs.gov/northwest

Authors: Tracy L. Fuentes, Marijke van Heeswijk, and Eric Grossman 